NBER WORKING PAPER SERIES

\author{
EFFECTS OF ALCOHOL \\ PRICE POLICY ON YOUTH
}

Michael Grossman

Frank J. Chaloupka

Henry Saffer

Adit Laixuthai

\begin{abstract}
Working Paper No. 4385
NATIONAL BUREAU OF ECONOMIC RESEARCH

1050 Massachusetts Avenue

Cambridge, MA 02138

June 1993
\end{abstract}

This paper is part of NBER's research programs in Health Economics and Public Economics. Any opinions expressed are those of the authors and not those of the National Bureau of Economic Research. 
NBER Working Paper \#4385

June 1993

\section{EFFECTS OF ALCOHOL PRICE POLICY ON YOUTH}

\section{ABSTRACT}

In this paper we summarize research that deals with the effects of alcoholic beverage prices and excise taxes on a variety of outcomes for youth. These include alcohol consumption, excessive consumption, motor vehicle accident mortality, and college completion rates. The research employs six nationally representative data sets on individuals that span the period from 1974 through 1989 and two state level data sets for the years 1975-1981 and 19821988. The studies find that alcohol use and motor vehicle accident mortality are negatively related to the cost of alcohol. College completion rates are positively related to this variable. Clearly, these are policy-relevant findings since price is a policy-manipulable variable. Frequently, the effects of a variety of simulated excise tax hikes exceed those of the uniform minimum legal drinking age of 21 in all states.

Michael Grossman

CUNY Graduate School

269 Mercer Street, 8th Floor

New York, NY 10003

(212) $995-3462$

and NBER

Henry Saffer

Kean College of New Jersey

269 Mercer Street, 8th Floor

New York, NY 10003

(212) 995-3455

and NBER
Frank J. Chaloupka

Department of Economics

University of Illinois at Chicago

601 South Morgan Street

Chicago, IL 60607-7121

and NBER

Adit Laixuthai

Health Resources Management

School of Public Health East

University of Illinois at Chicago

Box 6998

Chicago, IL 60680 


\section{EFFECTS OF ALCOHOL PRICE POLICY ON YOUTH}

\section{Introduction}

Since the mid-1970s, the Federal government of the United States and various state and local governments have campaigned to reduce deaths from motor vehicle accidents by discouraging alcohol abuse. Much of this campaign has focused on teenagers and young adults. This focus has been adopted because motor vehicle accident mortality is the leading cause of death of persons under the age of 35 , and alcohol is involved in over half these fatal crashes. In 1984 persons under the age of 25 accounted for 20 percent of all licensed drivers, but 35 percent of all drivers involved in fatal accidents (National Highway Traffic Safety Administration 1986). These figures are even more dramatic than they appear because members of the young driver group do not drive nearly as much as older drivers (Voas and Moulden 1980). Moreover, there is a pronounced negative relationship between age and abuse of or dependence on alcohol (Grant et al. 1991). It is also important to focus on the young because alcohol abuse in adolescence appears to be associated with alcohol abuse in later life (Rachal et al. 1980). Thus, policies to prevent the onset of this behavior in adolescents might be the most effective means to curb it in all segments of the population.

The major element of programs against adolescent alcohol abuse has been the upward trend in state minimum legal ages for the purchase and consumption of alcoholic beverages. This trend began with the increase in the 
legal drinking age in Minnesota from 18 to 19 years of age in 1976, and an additional 27 states had increased their legal drinking age by the time Congress passed the Federal Uniform Drinking Age Act of 1984. This act pressured all states into raising the minimum legal drinking age to 21 by withholding part of their Federal highway funding if they failed to comply. Currently all 50 states and the District of Columbia have a minimum drinking age of $21 .^{1}$

Other elements of the antidrinking campaign have been directed at all segments of the population. For example, the Alcohol Traffic Safety Act of 1983 provides financial incentives for states to enact and enforce new, more stringent drunk driving laws. These measures include more severe and certain penalties upon conviction of drunken driving, an easing of the standards required for conviction, and increased allocation of resources for the apprehension of drunken drivers. Approximately 500 new state and local laws resulted from this legislation (Ross 1990). A second example, Public Law $100-690$, requires that, as of November 1989, all alcoholic beverages sold in the United States must carry warning labels alerting consumers to such dangers as drunken driving and drinking during pregnancy.

While the above policies are vehicles to discourage alcohol abuse by youths and adults, increased taxation, which results in higher prices, is another policy that might significantly reduce this behavior. However, this vehicle has been virtually ignored in the antidrinking campaign. In January 1991, the Federal excise tax rates on beer and wine were increased for the first time 
since November 1951 , and the Federal excise tax rate on distilled spirits was raised for only the second time since 1951 . The tax on beer doubled from 16 cents per six-pack to 32 cents, the tax on wine jumped from just over 3 cents per 750 milliliter bottle to about 21 cents, and the tax on a 750 milliliter bottle of 80 proof distilled spirits rose from $\$ 1.98$ to $\$ 2.14$.

Even though the beer and wine tax hikes were substantial, they fell far short of the 25 cent tax per ounce of pure alcohol in any alcoholic beverage initially proposed by the Bush Administration. The actual rates are approximately 10 cents, 7 cents, and 21 cents for beer, wine, and distilled spirits, respectively. In addition, while Congress may have been persuaded by the health promotion aspects of higher alcohol taxes, the increases were well below those recommended by numerous public health organizations as prevention measures.

Like the Federal government, state and local governments have raised taxes on alcohol modestly and infrequently, almost always with the intent of increasing revenues rather than discouraging alcohol abuse. Due in part to the stability of these taxes, the real prices on alcoholic beverages (their prices after accounting for the effects of inflation) have declined significantly over time (see Figure 1). For example, between 1975 and 1990, the real price of distilled spirits fell by 32 percent; the real price of wine fell by 28 percent; and the real price of beer fell by 20 percent.

The recent increases in Federal taxes on beer and distilled spirits fall 
far short of those needed to offset the effects of inflation since 1951. For example in 1991, the distilled spirits tax rate would have had to have been 75 percent higher and the beer tax rate would have had to have been 162 percent higher to reach their real values as of 1951 . If alcohol abuse is sensitive to price, as economists have argued, then a policy of maintaining relatively low excise tax rates will exacerbate this problem. If alcohol consumption, particularly heavy consumption, is negatively affected by price and if alcohol problems are positively related to alcohol consumption, then increasing real excise tax rates will reduce alcohol consumption and its negative consequences. As a result, drinking and driving and other public health problems related to alcohol abuse will fall.

This article reviews the research by economists on the price sensitivity of alcohol use and abuse by youths. This review emphasizes the work by our colleagues, Douglas Coate and Gregory Arluck, and by us in the Health Economics Program at the National Bureau of Economic Research, dealing with the effects of taxes on drinking, heavy drinking, and drinking and driving among youth. In addition, it summarizes related research by Donald Kenkel of Pennsylvania State University and by Philip Cook and Michael Moore of Duke University. Since the policy to raise the minimum purchasing age to 21 has played such a prominent role in the antidrinking campaign, we compare tax or price effects with drinking age effects in a variety of individual and state-level data sets that span the period from 1974 through 1989. 
Before turning to a discussion of methods and results, we address some conceptual issues. A fundamental principle of economics is that of the downward sloping demand curve: as the price of any good rises, consumption of that good falls. Some economists have argued that the consumption of a potentially addictive good, such as alcohol, might be an exception to that rule. Numerous studies confirm, however, that this principle applies to the demand for alcoholic beverages (see Leung and Phelps in press for a detailed review of these studies and Manning, Blumberg, and Moulton 1992 for the most recent estimates pertaining to all segments of the population).

The studies just mentioned focus on the consumption of alcoholic beverages by adults or by all segments of the population. Yet there are reasons to believe that alcohol consumption by youth may be more sensitive to price than alcohol consumption by adults. One factor is that the fraction of disposable income that a youthful drinker spends on alcohol probably exceeds the corresponding fraction of an adult drinker. A second factor is that bandwagon or peer effects are much more important in the case of youth drinking than in the case of adult drinking (Rachel et al. 1980). Thus, a rise in price will curtail youth consumption directly and indirectly via its impact on peer consumption. Finally, youths are more likely to discount the future consequences of their current actions than adults. Becker, Grossman, and Murphy (1991) show that this makes youths more responsive to price than adults, while it makes adults more sensitive to changes in the perceived or 
actual harmful consequences that take place in the future.

Drinking age hikes have been shown to have negative effects on alcohol consumption, alcohol abuse, and motor vehicle accident mortality (see O'Malley and Wagenaar 1991 for the most recent of a number of studies). In comparing price or tax and drinking age policies, we realize that the uniform drinking age of 21 is unlikely to be lowered in the future. The aim of the comparisons is to gauge the magnitude of the tax policy by contrasting its impact with that of a policy that was advocated widely in the 1980s.

Of course, an effectively enforced prohibition of alcohol consumption by persons below the age of 21 should have a larger effect on their consumption than an increase in the excise tax rate. However, because of the problem of evasion, the effects of the minimum age law are diminished. Underage youths can obtain alcohol from their older siblings or friends. In addition, they can purchase fake identification cards or buy alcohol in stores that do not demand proof of age. This type of evasion simply is not possible with an excise tax hike, so that the responsiveness of youths to the price of alcohol determines the change in consumption.

Put differently, the "full" price of consuming alcohol equals the sum of the monetary price and the indirect price. An increase in the tax rate on alcohol raises the monetary price. From the point of view of an underage youth, an increase in the drinking age raises such indirect price components as the expected penalty for breaking the law, the dollar cost of a fake 
identification and the value of the time required to obtain one, and the value of the time required to find a store that does not demand proof of age. Thus tax hikes and drinking age hikes can be treated in a symmetrical manner. A ten cent increase in the tax rate raises the monetary price of alcohol by 10 cents. $^{2}$ A three year increase in the drinking age from 18 to 21 raises the indirect price of alcohol for an 18 year old by an unknown amount. In turn, this amount depends on how strictly or loosely the law is enforced. We will return to the issue of enforcement and its role in the design of optimal policies to curtail alcohol abuse after reviewing the empirical evidence.

\section{Methods}

The research on youth alcohol use discussed in this paper uses five nationally representative data sets. These are the first National Health and Nutrition Examination Survey (NHANES I), conducted by the National Center for Health Statistics (NCHS) from 1971 through 1974 (Grossman, Coate, and Arluck 1987); the second National Health and Nutrition Examination Survey (NHANES II), conducted by NCHS from 1976 through 1980 (Coate and Grossman 1988); the 1982 and 1989 surveys of high school seniors conducted by the University of Michigan's Institute for Social Research as part of the Monitoring the Future (MTF) project (our research with these two surveys is reported for the first time in this paper); and the 1985 National Health Interview Survey (NHIS) conducted by NCHS (Kenkel in press). The research on youth motor vehicle accident mortality is based on time series of 
state cross sections for the periods 1975-1981 (Saffer and Grossman 1987) and 1982-1988 (Chaloupka, Saffer, and Grossman in press). The study of alcohol consumption and college completion uses the National Longitudinal Survey of Youth (NLSY), which was begun in 1979 by Ohio State University's Human Resource Research Center and the U.S. Department of Labor (Cook and Moore 1992).

Much of this research focuses on the cost of beer and on the consumption of beer (where possible) because beer is the most popular alcoholic beverage among youth. It capitalizes on substantial differences in legal drinking ages among states and on substantial differences in alcoholic beverage prices among states primarily due to differences in state excise tax rates on these beverages. For example, in the period from 1974 through 1989 , state legal drinking ages ranged from 18 through 21 . In the same period, state excise tax rates on a case of 24-12 ounce cans of beer ranged from 4.5 cents in Wyoming to $\$ 2.28$ in Georgia.

The investigators add beer prices, taxes, and legal drinking ages to the NHANES I and II, the 1982 and 1989 MTF, the 1985 NHIS, and the NLSY based on a given youth's place of residence. Variants of multiple regression methods for categorical dependent variables are used to examine the effects of changes in beer prices or taxes and minimum legal drinking ages on the outcomes at issue while holding constant other determinants of these outcomes, including age, sex, race, and parental characteristics. The beer 
price and the state beer excise tax are used as alternative measures of the cost of beer because consistent beer price series are not available for all years in the survey periods. Results with these alternative measures are very similar.

In NHANES I, the outcome pertains to whether persons 16 to 21 years of age consume more than 5 cans of beer on a typical drinking day in the past year, 3-5 cans of beer on a typical drinking day, 1-2 cans of beer on a typical drinking day, or abstain from beer consumption. The NHANES II outcome identifies persons 16 to 21 years of age who consume beer 4-7 times a week in the past three months, 1-3 times a week, less than once a week, or never. Three alternative measures of alcohol consumption by high school seniors are employed in the 1982 and 1989 MTF. The first pertains to drinking in the past year and categorizes youths as frequent drinkers (more than 30 drinking occasions), fairly frequent drinkers (10 to 30 drinking occasions), infrequent drinkers (1 to 9 drinking occasions), and abstainers. The second focuses on drinking during the month prior to the survey and again defines youths as frequent drinkers (more than 9 occasions), fairly frequent drinkers (6 to 9 occasions), infrequent drinkers (1 to 5 occasions), and abstainers. The third focuses on heavy drinking, as defined by at least one drinking episode where five or more drinks were consumed in the two weeks before the survey. These data differ from the NHANES I and II data in that the alcoholic beverage consumed is unknown. The outcome in the 1985 NHIS is the number of days in the past year on which a person between the ages of 
18 and 21 had five or more drinks of any alcoholic beverage. The outcome in NLSY is college completion by persons between the ages of 14 and 15 at baseline.

In the motor vehicle accident mortality research, logit regressions are estimated for persons between the ages of 18 and 20 in two time series of state cross sections (1975-1981 and 1982-1988). In addition to the real beer excise tax rate (the sum of the Federal and state excise tax rate divided by the Consumer Price Index), other determinants of alcohol consumption and fatality rates are held constant. These include real income, measures of traffic, roadway, and vehicle conditions, driver characteristics, religious participation, and the fraction of the state population residing in counties prohibiting the sale of alcoholic beverages.

In the 1982-1988 data set, the effects of recent state legislation which discourages drinking and driving by raising the probability of arrest and conviction for driving under the influence of alcohol (DUD) and increasing the severity of the penalties associated with a DUI conviction also are examined. In this latter data set, three different fatality rates for both the overall population and youths ages 18 to 20 are examined. The first of these is the total motor vehicle accident fatality rate for each age group. In an attempt to focus on alcohol involvement in these fatalities, two additional, driver-specific fatality rates are defined. The first is limited to drivers killed between 12:00 a.m. and 3:59 a.m. and is called the nighttime driver fatality rate. The 
National Highway Traffic Safety Administration (1986) estimates that 75-90 percent of these drivers had been drinking. The second driver-specific fatality rate uses information on the blood alcohol concentration of drivers killed in traffic accidents and is called the alcohol involved driver fatality rate.

\section{Results}

The measures of alcohol use and motor vehicle accident mortality described above are negatively related to the cost of alcohol and to the legal drinking age. College completion rates are positively related to these two variables. All the estimated effects are statistically significant.

With regard to the magnitudes of the effects at issue, consider the beer consumption effects in NHANES II. A Federal policy that increases the tax on beer to offset the effects of inflation since 1951 would have reduced the percentage of youths who drink beer frequently (4-7 times a week) in NHANES II from 11.0 percent of the sample to 10.2 percent of the sample. Thus, the policy would have reduced the number of frequent beer drinkers by 7.3 percent. At the same time, it would have reduced the percentage of fairly frequent (1-3 times a week) beer drinkers from 28.0 percent to 26.5 percent or by 5.2 percent. If this policy were combined with one that raises the tax on the pure alcohol in beer to the same level as that on the pure alcohol in distilled spirits, the reductions in consumption would have been much sharper: a 32 percent reduction in the number of frequent youth drinkers and a 24 percent fall in the number of fairly frequent drinkers. The reductions 
predicted from this combined tax policy are greater than those associated with an alternative policy simulation: a uniform legal drinking age of 21 years. The latter policy would have reduced the number of frequent drinkers by 28 percent and the number of fairly frequent drinkers by 11 percent.

In Table 1 we use our estimates from the 1982 MFT high school senior survey to simulate the effects of a policy under which the legal drinking age is 21 in all states in that year and a policy under which the Federal excise tax is indexed to the rate of inflation since 1951. The inflation tax policy would have reduced the number of high school seniors who drank frequently (more than 30 times) in the past year ( 21 percent of all seniors) by 45 percent, the number who drank frequently (more than 9 times) in the past month (16 percent of all seniors) by 43 percent, and the number with at least one heavy drinking episode (consumption of five or more drinks) in the past two weeks (40 percent of all seniors) by 18 percent. These declines are quite large relative to the drinking age policy. Under the latter policy, the number of frequent drinkers in the past year would have declined by 8 percent, the number of frequent drinkers in the past month would have dropped by 9 percent, and the number of high school seniors with at least one heavy drinking episode in the past two weeks would have dropped by 4 percent.

Table 2 contains an inflation excise tax policy simulation based on our estimates for the 1989 MFT high school senior survey. The drinking age policy was not simulated because all states had a drinking age of 21 in that 
year. ${ }^{3}$ The predicted declines in the number of high school seniors who drank frequently in the past year or in the past month, or who drank heavily in the past two weeks associated with the excise tax policy are smaller in Table 2 than in Table 1. Based on the 1989 survey, the tax policy would have caused a 20 percent decline in the number of youths who drank frequently in the past year (13 percent of the 1989 sample), an 11 percent drop in the number of youths who drank frequently in the past month (10 percent of the sample), and a 7 percent fall in the number who drank heavily in the past two weeks (32 percent of the sample). Thus, the 1982 declines are between 2 and 4 times larger than the corresponding 1989 declines.

One explanation of this result is that high school seniors faced a higher indirect cost of obtaining alcohol in 1989 compared to 1982 due to the upward trend in the legal drinking age. Hence, the same percentage increase in the monetary price of beer in the two years represented a smaller percentage increase in the full price of this good in 1989. For example, if the drinking age policy effectively prohibited alcohol consumption by all persons below the age of 21 , an increase in the monetary price would have no impact on the full price. Clearly, since the declines associated with the inflation excise tax policy in Table 2 are bigger than those associated with the drinking age policy in Table 1, the upward trend in the drinking age has not prohibited alcohol consumption by high school seniors.

Kenkel's (in press) research with the 1985 NHIS indicates that a legal 
drinking age of 21 in that year would have caused approximately the same 18 percent reduction in the number of days in the past year on which a person between the ages of 18 and 21 had five or more drinks of alcohol as a Federal excise tax hike large enough to raise the price of beer by 14 percent. The inflation tax policies in Tables 1 and 2 would have raised the price of beer by approximately this percentage. Thus, Kenkel's estimates of the sensitivity of youth alcohol use to price relative to its sensitivity to the drinking age are somewhat smaller than ours. In part, this divergence is due to the differences in his outcome measures compared to ours. In particular, our heavy drinking measure pertains to the past two weeks and simply identifies high school seniors with at least one heavy drinking occasion in that period of time.

The main message of the research on youth alcohol use is that the incidence of frequent consumption and the incidence of heavy consumption are inversely related to the price of alcohol in nationally representative surveys. It is particularly notable that these effects emerge in three surveys in the 1980s: the 1982 MTF, the 1985 NHIS, and the 1989 MTF. This is because predictions of the effects of future tax hikes are on firmer ground if they are based on recent data. The research suggests that the negative price effects in the research with the two surveys in the 1970s--NHANES I and NHANES II-have not been diluted over time. Thus, if reductions in youth alcohol consumption and heavy consumption are desired, then the research indicates that an increase in the Federal excise tax on beer is effective in accomplishing 
this goal. These findings are particularly important since discouraging youth alcohol abuse is likely to lead to substantial future reductions in alcohol abuse among all individuals (recall the positive relationship between alcohol abuse in adolescence and alcohol abuse in later life reported by Rachel et al. 1980) and because frequent and/or heavier drinkers are likely to be responsible for a large percentage of youth motor vehicle crashes and deaths. Indeed, Kenkel (in press) reports a strong positive association between the number of days with five or more drinks of alcohol in the past year and the reported number of occasions of drunk driving in the past year.

With regard to the magnitudes of the motor vehicle accident mortality effects, Saffer and Grossman (1987) simulate the policies described above for 18 to 20 year olds in the period 1975-1981. The enactment of a minimum uniform drinking age of 21 in all states would have reduced the number of 18 to 20 -year-olds killed in motor vehicle crashes by 8 percent in that period. A policy that fixed the Federal excise beer tax in real terms since 1951 would have reduced the number of lives lost in fatal crashes by 15 percent, while a policy that taxed the alcohol in beer at the same rate as the alcohol in distilled spirits would have lowered the number of lives lost by 21 percent. A combination of the two tax policies would have caused a 54 percent decline in the number of youths killed. These reductions should be compared to the roughly 7,000 persons per year in this age category who died due to motor vehicle crashes in the period at issue. 
Table 3 shows simulated effects tax and drinking age policies for 18 to 20 year-olds based on the regression results in Chaloupka, Saffer, and Grossman (in press). The numbers in each cell give the absolute change in the number of youths killed in fatal crashes in a typical year in the period from 1982-1988 due to the policies identified in the first column. The figures in parentheses are percentage changes in fatality rates due to these policies. For comparative purposes, note that Saffer and Grossman's (1987) computations reveal that the lives of 1,022 youths aged 18 to 20 would have been saved in a typical year in the 1975-81 period if the Federal excise tax on beer had been indexed to the rate of inflation since 1951. On the other hand, the lives of 555 youths aged 18 to 20 per year would have been saved if the drinking age had been 21 in all states of the U.S.

The figures in Table 3 indicate that the impact of beer tax increases on youth motor vehicle fatalities in the mid 1980s should not be understated. If anything, these effects are bigger than those obtained by Saffer and Grossman for fatalities in the late 1970s. For instance, the inflation excise tax policy would have saved 1,660 lives per year in the $1982-88$ period or more than one and a half times the number of lives per year saved by the same policy in the $1975-81$ period. This policy also would have cut the number of nighttime driver fatalities and the number of alcohol involved driver fatalities by 40 percent in each case. Initially, the Bush Administration proposed a tax of 25 cents per ounce of pure alcohol in beer or 81 cents per six-pack. 
According to our estimates, this policy would have saved 527 more lives per year in the mid and late 1980s than the inflation tax policy.

The 1991 increase in the Federal excise tax on beer from 16 cents per six-pack to 32 cents would have reduced the number of youths killed in fatal crashes by 611 per year if it had been enacted nine years earlier. While this saving in lives is much smaller than under either of the two tax policies discussed above, it is larger than the 166 additional lives saved per year under a 21 year old minimum legal purchase age in all states in the period 1982-88 or the 498 additional lives lost under an 18 year old minimum purchase age in all states in the same period. Put differently, the gain in lives from going to an 18 year old purchasing age in all states to a 21 year old purchasing age in all states amounts to 664 lives. This is approximately equal to the lifesaving impact of a doubling in the beer tax and only two-fifths as large as the life-saving effect of a policy that indexes the beer tax to the rate of inflation since 1951. As in the case of the youth alcohol use studies, the basic conclusion to be drawn from the research on motor vehicle accident fatalities is that increases in alcoholic beverage taxes are an effective means of accomplishing the goal of reductions in drunken driving and related deaths in traffic crashes among youth.

\section{Discussion}

Can one compute the appropriate or optimal tax on alcohol based on the studies summarized in this paper? The answer is "a qualified yes," once 
the results of other studies are considered.

In the language of economics, alcohol use and abuse impose significant external costs. That is, at least part of the costs associated with alcohol abuse are borne by those other than the abuser. These include the loss of life, injuries, and property damage associated with drunken driving and other accidents, loss of life from violent crime, increased health care and insurance costs, and lost productivity costs. Pogue and Sgontz (1989) and Manning et al. (1989) report these external abuse costs as approximately $\$ 175$ per gallon of pure alcohol, in 1991 prices. 4

To determine the optimal excise tax on alcohol, the reduction in external costs due to tax hikes must be weighed against the increase in costs imposed on society by the tax (the welfare costs of the tax). The imposition of an alcohol excise tax or an increase in its rate results in a loss of consumer surplus--defined as the difference between the value of alcohol to consumers and the amount that they pay for it. Consumer surplus arises because each unit of a good is sold at the same price. This price equals the value of the marginal or last unit purchased by the consumer. Other units are more highly valued than the marginal unit. The welfare costs of the tax equal the loss in consumer surplus minus the revenue generated from the tax. The increase in $\operatorname{tax}$ revenue, which is always smaller than the loss in consumer surplus, represents a gain for members of society and must be subtracted from loss in consumer surplus to obtain the welfare cost of the tax. 
Based on these notions, Pogue and Sgontz (1989) Manning et al. (1989), and Saffer and Chaloupka (1992) estimate the optimal tax on alcohol in 1991 at $\$ 73, \$ 78$, and $\$ 79$ per gallon of pure alcohol, respectively. In 1991, the actual average tax on a gallon of pure alcohol was approximately $\$ 35$. This suggests that alcohol taxes could be more than doubled before the costs of the increased taxes would begin to exceed their benefits. ${ }^{s}$

The studies cited above determine optimal tax rates in the context of alcohol abuse among all segments of the population. In a study limited to abuse among teenagers and young adults, Phelps (1988) makes use of estimates of the effects of beer taxes on youth alcohol abuse and motor vehicle accident mortality provided by Grossman, Coate, and Arluck (1987) and Saffer and Grossman (1987) to compute the optimal tax of beer. His optimal tax lies in the range of 25 to 40 percent or more of the price of beer. The 1991 rate of approximately 16 percent (inclusive of Federal and state beer taxes) is much smaller than this range. Moreover, Phelps excludes the value of the higher college completion rates due to excise tax hikes reported by Cook and Moore (1992).

To highlight the effectiveness of the tax policy, suppose that one had to choose between this policy and a policy to discourage youth alcohol abuse by raising the minimum legal drinking age from 18 to 21 . Note that the drinking age is unlikely to fall to 18 in the near future, and we are not necessarily advocating a choice between these two policies. This hypothetical 
choice involves a similar comparison to the one made above of the welfare costs and benefits (reductions in external costs) of the two policies. One factor that favors the drinking age policy in this comparison is that excise tax hikes impose welfare costs on all segments of the population, while minimum age laws are targeted at the group in the population that accounts for a disproportionate share of motor vehicle accidents and deaths. Two factors, however, go in the opposite direction. First, the enforcement and administrative costs associated with a uniform drinking age of 21 are likely to be much higher than those associated with the tax policy. Second, as emphasized by Kenkel (1992), the loss in consumer surplus due to a rise in the drinking age cannot in this case be partially offset by an increase in tax revenue because there is no increase in revenue.

Kenkel (1992) focuses on the welfare cost aspect of the above choice by comparing policies with the same benefits in terms of reductions in youth alcohol abuse. He considers two specific options: a uniform drinking age of 21 as opposed to 18 and an excise tax hike large enough to raise the price of alcohol by approximately 14 percent. Note that the 1991 Federal beer tax rate of 84 cents per six-pack required to fully adjust for inflation since 1951 would have raised the price of a six pack by roughly 14 percent. Using an estimate of the price elasticity of demand for alcohol (the percentage reduction in consumption caused by a one percent increase in price) of -.7 , he finds that the welfare costs of the drinking age policy are approximately one and a half times 
larger than the welfare costs of the tax policy because the reduction in consumer surplus cannot be offset by an increase in tax revenue when the drinking age rises. This finding does not take account of the costs of enforcing a minimum purchasing age of 21 .

In conclusion the research that we have summarized suggests that, if reductions in youth alcohol consumption, heavy alcohol consumption, and alcohol related injuries and deaths are desired, an increase in Federal taxes on alcoholic beverages is an effective policy to accomplish these goals. Furthermore, current estimates of the external costs associated with alcohol abuse indicate that the appropriate taxes on alcohol should be substantially higher than current taxes. The tax policy appears to be more potent than a uniform drinking age of 21 , and the welfare costs of the former appear to be smaller than those of the latter. Combined with Kenkel's (forthcoming) conclusion that the welfare costs of policies to deter drunken driving exceed those of tax or drinking age initiatives, the evidence in this paper highlights the extremely favorable cost-benefit ratio of tax policy as a vehicle to reduce drunken driving and other negative consequences of excessive alcohol consumption. 


\section{FOOTNOTES}

Research for this paper was supported by grant 5 R01 AA08359 from the National Institute on Alcohol Abuse and Alcoholism to the National Bureau of Economic Research. We are indebted to Patrick M. O'Malley and Jerome J. Hiniker of the University of Michigan's Institute for Social Research (ISR) for providing us with restricted datasets from the Monitoring the Future surveys of 1982 and 1989 containing county identifiers. We also are indebted to Jan Howard and three anonymous referees for helpful comments on an earlier draft. This paper has not undergone the review accorded official NBER publications; in particular, it has not been submitted for approval by the Board of Directors.

${ }^{1}$ The last two Surgeon Generals of the U.S., Antonia Novello and C. Everett Koop, have advocated policies under which beer and wine companies would stop broadcasting commercials aimed at children and adolescents on radio and television, although the industry denies that they target youth. These efforts are part of a broader strategy to curtail or ban broadcast advertising of beverage alcohol in general or to require the alcoholic beverage industry or the broadcast media to finance antidrinking advertising on radio and television. This policy is still in the discussion stage.

${ }^{2}$ This assumes that the alcoholic beverage industry is competitive and has a perfectly elastic supply function. These conditions are necessary for all of 
the increase in the tax to be shifted from producers to consumers. Grossman's preliminary research on the determinants of beer prices in the American Chamber of Commerce Researchers Association quarterly survey suggests that a ten cent increase in the state excise tax rate on beer raises the price of beer by approximately ten cents. Cook (1981) estimates that a ten cent increase in the state excise tax rate on distilled spirits raises the price of distilled spirits by twelve cents.

${ }^{3}$ Since some state drinking laws enacted in the late 1980 s contained grandfather clauses, the effective legal drinking age was not 21 in all states until the middle of 1990. But there was little variation in effective legal drinking ages among states in 1989.

${ }^{4}$ The classification of the costs that abusers impose upon themselves is not clear. These are not external costs if the abusers are fully informed about the consequences of their actions but are external costs in the case of completely uninformed abusers. In intermediate cases some portion of these costs should be included in the benefits from reductions in abuse. The studies cited above present ranges of estimates based on alternative classifications of the costs that abusers impose upon themselves.

${ }^{5}$ To maintain the optimal tax in real terms after 1991, it would have to be indexed to the rate of inflation. The same objective could be accomplished by converting to an ad valorem alcoholic beverage excise tax system. Under this 
system, the tax rate is expressed as a fixed percentage of price. 


\section{REFERENCES}

Becker, Gary S.; Grossman, Michael; and Murphy, Kevin M. "Rational Addiction and the Effect of Price on Consumption." American Economic Review, 81, No. 2 (May 1991), 237-241.

Chaloupka, Frank J.; Saffer, Henry; and Grossman, Michael. "Alcohol Control Policies and Motor Vehicle Fatalities." Journal of Legal Studies, in press.

Coate, Douglas, and Grossman, Michael. "Effects of Alcoholic Beverage Prices and Legal Drinking Ages on Youth Alcohol Use." Journal of Law and Economics, 31, No. 1 (April 1988), 145-171.

Cook, Philip J. "The Effect of Liquor Taxes on Drinking, Cirrhosis, and Auto Fatalities." In Alcohol and Public Policy: Beyond the Shadow of Prohibition, edited by Mark H. Moore and Dean R. Gerstein. Washington, D.C: National Academy Press, 1981, 255-285.

Cook, Philip J., and Moore, Michael J. "Drinking and Schooling." Presented at the Third Annual Health Economics Workshop at Johns Hopkins University, Baltimore, Maryland, May 1992.

Grant, Bridget F.; Hartford, Thomas C.; Chou, Patricia; Pickering, Roger; Dawson, Deborah A.; Stinson, Frederick S.; and Noble, John. "Prevalence of DSM-III-R Alcohol Abuse and Dependence." Alcohol Health \& Research World, 15, No. 1 (1991), 91-96. 
Grossman, Michael; Coate, Douglas; and Arluck, Gregory M. "Price Sensitivity of Alcoholic Beverages in the United States." In Control Issues in Alcohol Abuse Prevention: Strategies for States and Communities, edited by Harold D. Holder. Greenwich, Connecticut: JAI Press, Inc., 1987, 169-198.

Kenkel, Donald S. "Drinking, Driving, and Deterrence: The Social Costs of Alternative Policies." Journal of Law and Economics, in press.

Kenkel, Donald S. "Prohibition versus Taxation: Reconsidering the Legal Drinking Age." Working Paper, Department of Economics, Pennsylvania State University, June 1992.

Leung, Siu Fai., and Phelps, Charles E. 'MMy Kingdom for a Drink....?' A Review of the Price Sensitivity of Demand for Alcoholic Beverages." In Economic and Socioeconomic Issues in the Prevention of AlcoholRelated Problems, edited by Gregory Bloss and Michael Hilton. Rockville, Maryland: National Institute on Alcohol Abuse and Alcoholism, in press.

Manning, Willard G.; Blumberg, Linda; and Moulton, Lawrence H. "The Demand for Alcohol: The Differential Response to Price." Presented at the Third Annual Health Economics Workshop at Johns Hopkins University, Baltimore, Maryland, May 1992. 
Manning, Willard G.; Keeler, Emmett B.; Newhouse, Joseph P.; Sloss, Elizabeth M.; and Wasserman, Jeffrey. "The Taxes of Sin: Do Smokers and Drinkers Pay Their Way?" Journal of the American Medical Association, 261, No. 11 (March 1989), 1604-1609.

National Highway Traffic Safety Administration, U.S. Department of Transportation. Fatal Accident Reporting System, 1984. DOT HS 806 919, February 1986.

O'Malley, Patrick M., and Wagenaar, Alexander C. "Effects of Minimum Drinking Age Laws on Alcohol Use, Related Behaviors and Traffic Crash Involvement among American Youth: 1976-1987." Journal of Studies on Alcohol, 52, No. 5 (1991), 478-491.

Phelps, Charles E. "Death and Taxes: An Opportunity for Substitution." Journal of Health Economics, 7; No. 1 (March 1988), 1-24.

Pogue, Thomas F., and Sgontz, Larry G. "Taxing to Control Social Costs: The Case of Alcohol." American Economic Review, 79, No. 1 (March 1989), 235- 243.

Rachal, J. Valley; Guess, L. Lynn; Hubbard, Robert L.; Maisto, Stephen A; Cavanaugh, Elizabeth R.; Waddell, Richard; and Benrud, Charles H. "The Extent and Nature of Adolescent Alcohol Abuse: The 1974 and 1978 National Sample Surveys." Prepared for the National Institute on Alcohol Abuse and Alcoholism. Springfield, Virginia: U.S. National Technical Information Service, 1980. 
Ross, H. Laurence. "Deterring Drunken Driving: An Analysis of Current Efforts." Alcohol Health and Research World, 14, No. 1 (1990), 5862.

Saffer, Henry, and Chaloupka, Frank J. "Alcohol Tax Equalization and Social Cost." Working Paper, National Bureau of Economic Research, July 1992.

Saffer, Henry, and Grossman, Michael. "Beer Taxes, the Legal Drinking Age, and Youth Motor Vehicle Fatalities." Journal of Legal Studies, 16, No.2 (June 1987), 351-374.

Voas, Robert B., and Moulden, John. "Historical Trends in Alcohol Use and Driving by Young Americans." In Minimum Drinking Age Laws: An Evaluation, edited by Henry Wechsler. Lexington, Massachusetts: D.C. Heath and Company, 1980, 59-72. 


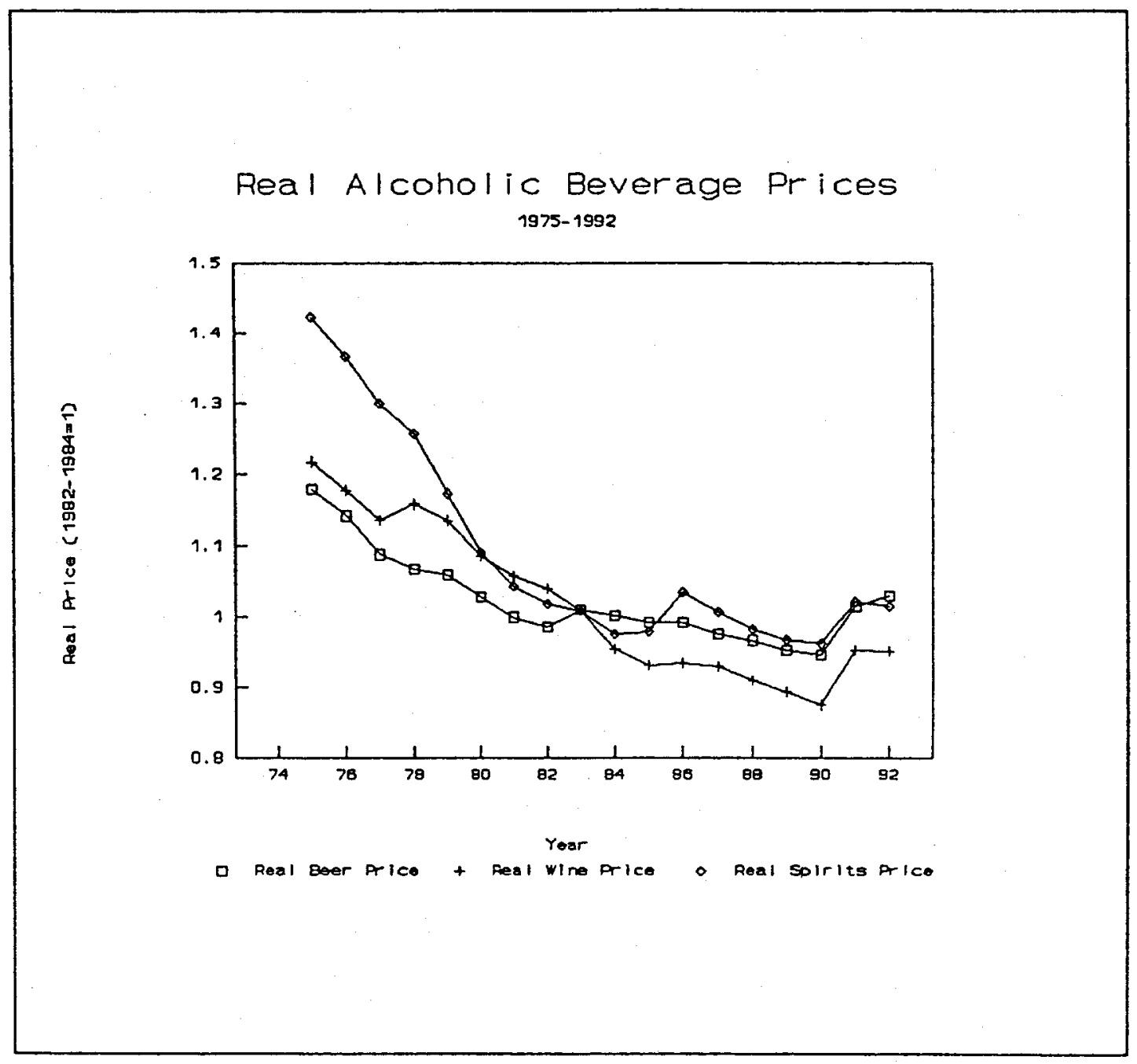

* 1992 prices are for the first quarter. Distilled spirits prices from 1975 through 1977 are based on the whiskey price index. All data used for the figure are from Bureau of Labor Statistics, U.S. Department of Labor, Monthly Labor Review, various issues and Consumer Price Index-Detailed Report, various issues. 
Table 1

High School Senior Alcohol Use, Legal Drinking Ages, and Beer Excise Taxes, 1982

\begin{tabular}{|c|c|c|c|}
\hline Outcome & $\begin{array}{c}\text { Actual } \\
\text { Distribution }\end{array}$ & $\begin{array}{l}\text { Drinking } \\
\text { Age } \\
\text { Policy }\end{array}$ & $\begin{array}{l}\text { Inflation } \\
\text { Tax } \\
\text { Policy }^{\circ}\end{array}$ \\
\hline \multicolumn{4}{|l|}{ Panel A: Drinking in Past Year } \\
\hline Abstainers (no drinking occasions) & $12.8 \%$ & +10.6 & +80.1 \\
\hline Infreqent Drinkers (1-9 drinking occasions) & $36.3 \%$ & +3.2 & +15.8 \\
\hline $\begin{array}{l}\text { Fairly Frequent Drinkers (10-30 drinking } \\
\text { occasions) }\end{array}$ & $30.1 \%$ & -2.5 & -19.7 \\
\hline $\begin{array}{l}\text { Frequent Drinkers (more than } 30 \text { drinking } \\
\text { occasions) }\end{array}$ & $20.8 \%$ & -8.3 & .45 .2 \\
\hline \multicolumn{4}{|l|}{ Panel B: Drinking in Past Month } \\
\hline Abstainers (no drinking occasions) & $30.1 \%$ & +7.6 & +42.0 \\
\hline Infrequent Drinkers (1-5 drinking occasions) & $41.4 \%$ & -0.3 & -5.4 \\
\hline $\begin{array}{l}\text { Fairly Frequent Drinkers (6-9 drinking } \\
\text { occasions) }\end{array}$ & $13.0 \%$ & -5.2 & -27.7 \\
\hline $\begin{array}{l}\text { Frequent Drinkers (more than } 9 \text { drinking } \\
\text { occasions) }\end{array}$ & $15.5 \%$ & -9.2 & -43.0 \\
\hline \multicolumn{4}{|l|}{$\begin{array}{c}\text { Panel C: Heavy Drinking in Past Two Weeks } \\
\text { (one or more episodes of consumption of at } \\
\text { least five drinks in a row) }\end{array}$} \\
\hline No Heavy Drinking Episodes & $59.7 \%$ & +2.6 & +12.0 \\
\hline At Least One Heavy Drinking Episode & $40.3 \%$ & -4.1 & -18.4 \\
\hline
\end{tabular}

- The drinking age policy pertains to a minimum legal purchasing age of 21 in all states. Figures represent the percentage change in the number of youths in each category.

- Indexing the Federal beer excise tax to inflation since 1951 implies a tax of approximately 59 cents per six pack in 1982. Figures represent the percentage change in the number of youths in each category. 
Table 2

High School Senior Alcohol Use and Beer Excise Taxes, 1989

\begin{tabular}{|c|c|c|}
\hline Outcome & $\begin{array}{c}\text { Actual } \\
\text { Distribution }\end{array}$ & $\begin{array}{l}\text { Inflation } \\
\text { Tax } \\
\text { Policy }\end{array}$ \\
\hline \multicolumn{3}{|l|}{ Panel A: Drinking in Past Year } \\
\hline Abstainers (no drinking occasions) & $15.3 \%$ & +21.5 \\
\hline Infrequent Drinkers (1-9 drinking occasions) & $44.4 \%$ & +3.8 \\
\hline $\begin{array}{l}\text { Fairly Frequent Drinkers (10-30 drinking } \\
\text { occasions) }\end{array}$ & $27.1 \%$ & -8.8 \\
\hline $\begin{array}{l}\text { Frequent Drinkers (more than } 30 \text { drinking } \\
\text { occasions) }\end{array}$ & $13.2 \%$ & -19.6 \\
\hline \multicolumn{3}{|l|}{ Panel B: Drinking in Past Month } \\
\hline Abstainers (no drinking occasions) & $39.2 \%$ & +6.2 \\
\hline Infrequent Drinkers (1-5 drinking occasions) & $41.2 \%$ & -1.8 \\
\hline $\begin{array}{l}\text { Fairly Frequent Drinkers (6-9 drinking } \\
\text { occasions) }\end{array}$ & $6.9 \%$ & -6.6 \\
\hline $\begin{array}{c}\text { Frequent Drinkers (more than } 9 \text { drinking } \\
\text { occasions) }\end{array}$ & $10.1 \%$ & -10.1 \\
\hline \multicolumn{3}{|l|}{$\begin{array}{c}\text { Panel C: Heavy Drinking in Past Two Weeks } \\
\text { (one or more episodes of consumption of at } \\
\text { least five drinks in a row) }\end{array}$} \\
\hline No Heavy Drinking Episodes & $68.1 \%$ & +3.1 \\
\hline At Least One Heavy Drinking Episode & $31.9 \%$ & -6.5 \\
\hline
\end{tabular}

- Indexing the Federal beer excise tax to inflation since 1951 implies a tax of approximately 76 cents per six pack in 1989. Figures represent the percentage change in the number of youths in each category. 


\section{Table 3}

Motor Vehicle Accident Mortality Simulations, 18 to 20 Year-Olds, 1982-88

\begin{tabular}{|l|l|l|l|}
\hline Simulation & $\begin{array}{l}\text { Total } \\
\text { Traffic } \\
\text { Fatalities }\end{array}$ & $\begin{array}{l}\text { Nighttime } \\
\text { Driver } \\
\text { Fatalities }\end{array}$ & $\begin{array}{l}\text { Alcohol } \\
\text { Involved } \\
\text { Driver } \\
\text { Fatalities }\end{array}$ \\
\hline $\begin{array}{l}\text { Real beer tax maintains 1951 value - increase } \\
\text { nominal tax with CPI (71.6\% per 6-pack in } \\
1988)\end{array}$ & $\begin{array}{c}-1,660 \\
(-32.1 \%)\end{array}$ & $\begin{array}{l}-379 \\
(-39.1 \%)\end{array}$ & $\begin{array}{l}-739 \\
(-40.3 \%)\end{array}$ \\
\hline $\begin{array}{l}\text { Impose a tax of 25\& per ounce of pure } \\
\text { alcohol in beer (81є per 6-pack) }\end{array}$ & $\begin{array}{c}-2,187 \\
(-42.2 \%)\end{array}$ & $\begin{array}{l}-491 \\
(-50.7 \%)\end{array}$ & $\begin{array}{l}-957 \\
(-52.3 \%)\end{array}$ \\
\hline $\begin{array}{l}\text { Deficit Reduction tax increase - doubling of } \\
\text { the beer tax to 32e per six-pack }\end{array}$ & $\begin{array}{c}-611 \\
(-11.8 \%)\end{array}$ & $\begin{array}{l}-145 \\
(-14.9 \%)\end{array}$ & $\begin{array}{l}-285 \\
(-15.6 \%)\end{array}$ \\
\hline $\begin{array}{l}\text { 21 year old minimum legal purchase age in } \\
\text { all states }\end{array}$ & $\begin{array}{c}-166 \\
(-3.2 \%)\end{array}$ & $\begin{array}{l}-42 \\
(-4.4 \%)\end{array}$ & $\begin{array}{l}-138 \\
(-7.5 \%)\end{array}$ \\
\hline $\begin{array}{l}\text { 18 year oid minimum legal purchase age in } \\
\text { all states }\end{array}$ & $\begin{array}{c}+498 \\
(+9.6 \%)\end{array}$ & $\begin{array}{l}+118 \\
(+12.1 \%)\end{array}$ & $\begin{array}{l}+389 \\
(+21.3 \%)\end{array}$ \\
\hline
\end{tabular}

"Each cell contains estimates of the absolute change in fatalities per year, on average, of the simulated policy (first row) and the percentage change in the fatality rate resulting from the policy simulation (second row in parentheses). 